Article

\title{
Operating of Gasoline Engine Using Naphtha and Octane Boosters from Waste as Fuel Additives
}

\author{
Obed Majeed Ali ${ }^{1}$ (D), Omar Rafae Alomar ${ }^{2}$, Omar Mohammed Ali ${ }^{3}$, Naseer T. Alwan ${ }^{4,5}$ (D), Salam J. Yaqoob ${ }^{6, *(D)}$, \\ Anand Nayyar ${ }^{7}$ (D) Sameh Askar 8 (D) and Mohamed Abouhawwash 9,10 (D)
}

check for

updates

Citation: Ali, O.M.; Alomar, O.R.; Ali, O.M.; Alwan, N.T.; Yaqoob, S.J.; Nayyar, A.; Askar, S.; Abouhawwash, M. Operating of Gasoline Engine Using Naphtha and Octane Boosters from Waste as Fuel Additives. Sustainability 2021, 13, 13019. https:// doi.org/10.3390/su132313019

Academic Editors: João Carlos de Oliveira Matias and Paolo Renna

Received: 10 November 2021 Accepted: 20 November 2021 Published: 24 November 2021

Publisher's Note: MDPI stays neutral with regard to jurisdictional claims in published maps and institutional affiliations.

Copyright: (c) 2021 by the authors. Licensee MDPI, Basel, Switzerland. This article is an open access article distributed under the terms and conditions of the Creative Commons Attribution (CC BY) license (https:/ / creativecommons.org/licenses/by/ $4.0 /)$.
1 Renewable Energy Research Unit, Northern Technical University, Kirkuk 36001, Iraq; obedmajeed@gmail.com

2 Engineering Technical College of Mosul, Northern Technical University, Mosul 41002, Iraq; omar.alomar@ntu.edu.iq

3 College of Mechanical Engineering, University of Zakho, Zakho 42002, Iraq; omar.ali@uoz.edu.krd

4 Department of Nuclear and Renewable Energy, Ural Federal University, 620002 Yekaterinburg, Russia; nassir.towfeek79@gmail.com

5 Technical Engineering College of Kirkuk, Northern Technical University, Kirkuk 36001, Iraq

6 Department of Research and Education, Authority of the Popular Crowd, Baghdad 10001, Iraq

7 Faculty of Information Technology, Graduate School, Duy Tan University, Da Nang 550000, Vietnam; anandnayyar@duytan.edu.vn

8 Department of Statistics and Operations Research, College of Science, King Saud University, P.O. Box 2455, Riyadh 11451, Saudi Arabia; saskar@ksu.edu.sa

9 Department of Computational Mathematics, Science, and Engineering (CMSE), College of Engineering, Michigan State University, East Lansing, MI 48824, USA; abouhaww@msu.edu

10 Department of Mathematics, Faculty of Science, Mansoura University, Mansoura 35516, Egypt

* Correspondence: engsalamjabr@gmail.com

Abstract: Fuel quality is an important indicator for the suitability of alternative fuel for the utilization in internal combustion (IC) engines. In this paper, light naphtha and fusel oil have been introduced as fuel additives for local low octane gasoline to operate a spark ignition (SI) engine. Investigated fuel samples have been prepared based on volume and denoted as GN10 (90\% local gasoline and 10\% naphtha), GF10 (90\% local gasoline and 10\% fusel oil), and GN5F5 (90\% local gasoline, 5\% naphtha and 5\% fusel oil) in addition to G100 (Pure local gasoline). Engine tests have been conducted to evaluate engine performance and exhaust emissions at increasing speed and constant wide throttle opening (WTO). The study results reveal varying engine performance obtained with GN10 and GF10 with increasing engine speed compared to local gasoline fuel (G). Moreover, GN5F5 shows higher brake power, lower brake specific fuel consumption, and higher brake thermal efficiency compared to other investigated fuel samples over the whole engine speed. The higher $\mathrm{CO}$ and $\mathrm{CO}_{2}$ emissions were obtained with GN10 and GF10, respectively, over the entire engine speed and the minimum $\mathrm{CO}$ emissions observed with GN5F5. Moreover, the higher $\mathrm{NO}_{\mathrm{x}}$ emission was observed with pure local gasoline while the lowest was observed with GF10. On the other hand, GN5F5 shows slightly higher $\mathrm{NO}_{\mathrm{x}}$ emissions than GF10, which is lower than GN10 and gasoline. Accordingly, GN5F5 shows better engine performance and exhaust emissions, which can enhance the local low gasoline fuel quality using the locally available fuel additives.

Keywords: naphtha; SI engine; fusel oil; engine performance; exhaust emissions; fuel additives; thermal efficiency

\section{Introduction}

Global warming and increasing energy demand engage researchers to search for a suitable alternative to reduce the dependence on mineral fuel. Petroleum fuel currently represents a significant share among other fuel sources [1-3]. The primary energy-consuming sectors in the world are industry and transportation, which depend mainly on IC engines that consume liquid mineral fuel. The utilization of this fuel is restricted by the limited 
sources, increasing price, and environmental pollution [4-6]. Furthermore, the combustion emissions of mineral fuel can be considered as the primary contributor to environmental pollution. Therefore, many agreements have been legislated to restrict the increasing global warming, which indicates the utilization of high quality fuels that combust efficiently with fewer pollutants to achieve this target [7-10].

Though many alternative fuels have been suggested by different researchers to be used in SI engine [8,11-14], petroleum based fuel is the most dominant. Hence, focusing on the utilization of high fuel quality to enhance the fuel combustion efficiency is a viable option to face the energy crises challenge and global warming [15]. Fusel oil is a byproduct of the waste products processed by the method of fermentation. The high oxygen content and octane number of fusel oil attract researchers to introduce fusel oil as fuel for SI engines [16,17]. Naphtha is one of the leading products of refineries. It is used in many industries like the petrochemical industry as a feedstock, gasoline fuel blend, and widely as a diluent [18-21]. The biggest producer of naphtha worldwide is the Middle East. The major share of this product is consumed by countries with substantial petrochemical interests, like Korea and Japan, which are considered the leading importers [18].

Naphtha is a light, highly flammable mixture produced from the tar of coal, refined petroleum, or shale gas. Naphtha can be classified into three main types, including the light naphtha, which is used as a gasoline fuel blend and widely in the petrochemical industry [22-24]. Medium naphtha can also be used as a gasoline fuel blend and offers a more comprehensive range of uses in reforming or the petrochemical industry. The last type of naphtha is the heavy naphtha used mainly to produce or improve gasoline components [25]. Light naphtha is composed of pentane and slightly heavier material. It is produced from crude oil distillation or natural gas liquid (NGLs) separation and, in this case, called natural gasoline or pentanes plus [12,19,25-27]. Light naphtha is often blended directly with gasoline in the refinery up to $5 \%$ blending ratio due to its low octane number and relatively high vapour pressure, which limits utilization at a higher percentage [19].

Naphtha is used as a source for fuel production due to its large energy content, where the amount of created chemical energy measured to be 3.14 megajoules of energy per litter [28-30]. Moreover, naphtha is used in many other applications as a fuel, including stoves, heating units, lanterns, cigarette lighters, and blowtorches due to its clean-burning in addition to its utilization as a fuel additive [31].

Wang et al. [29] studied the auto ignition characteristics of gasoline-naphtha blend fuel spray in a constant volume optically accessible combustion chamber using light naphtha at different blending ratios. Varying ignition delay was used to achieve auto-ignition of the tested fuel samples according to the adopted experimental conditions. The obtained results reveal the random distribution of the auto-ignition in the combustion chamber with similar spray angle and front penetration length before auto-ignition.

In another study, Wang et al. [32] conducted an experimental investigation to evaluate the impact of naphtha addition with commercial gasoline on the two-stage combustion characteristics of multiple premixed compression ignition (MPCI) mode. The study results reveal that adding naphtha results in achieving stable combustion in a wide load range. Furthermore, higher thermal efficiency is obtained for naphtha and gasoline in MPCI mode than diesel in CDC mode due to the low heat transfer loss for gasoline and low exhaust loss for naphtha. To control $\mathrm{NO}_{\mathrm{x}}$ emissions within the limits of EURO VI, separated combustion in MPCI is essential to reduce cylinder temperature with a moderate EGR ratio below 30\%.

Wang et al. [20] conducted a study to investigate the performance of modern SI engine operation with a blend of gasoline fuel and gas to liquid naphtha at full load conditions. Thermal analysis was conducted for correlating fuel properties with experimental engine data. The obtained results reveal comparable combustion characteristics and exhaust emissions for the investigated fuel with the standard EN228 gasoline fuel at full load conditions. Furthermore, the fuel consumption with the tested fuel blend was found to be higher than that of gasoline due to the reduced octane rating caused by naphtha. Moreover, 
lower particulate emissions were measured with gasoline fuels containing up to $15.4 \mathrm{vol} . \%$ naphtha compared to gasoline.

Simsek and Uslu [33] introduced fusel oil with different ratios (0-30\%) to operate spark ignition (SI) engine as an alternative energy source to gasoline at different engine compression ratios and operation conditions. Their study finding indicates the future focus of similar research concerning the optimization of blended fusel oil-gasoline fuel. Similar work has found that fusel oil and gasoline blend at different ratios can be employed for operating engines [34]. The same optimization concept has been used to indicate the optimum operating parameters at $10 \%$ and $20 \%$ fusel oil ratio with gasoline [35].

All the studies mentioned above listed that the utilization of fusel oil can mitigate fuel combustion pollution. However, the low calorific value restricted the utilization of fusel oil at a high percentage ratio with gasoline. Furthermore, though naphtha has a low octane number, it contains a large amount of chemical energy. Based on the author's knowledge, no study has been conducted to investigate the addition of light naphtha and fusel fuel as a low octane blend to the local commercial gasoline.

This study investigates the addition of fusel oil as an octane enhancer and naphtha as an additive with high energy content to the local low octane gasoline fuel. An engine test has been conducted with different fuel samples to evaluate the engine performance and exhaust emissions compared to pure local gasoline as a threshold.

The proposed research is organized as follows. Section 2 introduces the methodology. Section 3 presents the results and discussion. Section 4 highlights the conclusions of the paper.

\section{Methodology}

\subsection{Fuel Preparation}

A blend of local low octane gasoline, light naphtha and fusel oil was used to operate a gasoline engine. Properties of the selected fuel are shown in Table 1. Local low octane gasoline was supplied from a local petrol station in Kirkuk, Iraq. Light naphtha was supplied by a local chemical company while fusel oil was provided by Eskişehir sugar factory, Turkey. The investigated fuel blend denoted as G100 (Pure Local gasoline), GN10 (90\% Local gasoline and 10\% naphtha), GF10 (90\% Local gasoline and 10\% fusel oil), and GN5F5 (90\% Local gasoline, 5\% naphtha and 5\% fusel oil). Each fuel sample was prepared based on volume and mixed using a magnetic stirrer for about $20 \mathrm{~min}$ at $2000 \mathrm{rpm}$ to ensure a homogenous fuel blend. Prepared fuel samples were stored in airtight glass bottles in the laboratory at room temperature for the engine test.

Table 1. Properties of local gasoline, light naphtha and fusel oil [4,21].

\begin{tabular}{cccc}
\hline Parameters & Local Gasoline & Light Naphtha & Fusel Oil \\
\hline Oxygen cc & - & - & 18 \\
H/C ratio & 2.25 & 2.34 & - \\
Density $\left(\mathrm{kg} / \mathrm{m}^{3}\right)$ at $20 \mathrm{C}$ & 765 & 654 & 800.3 \\
RON & 41.8 & 45.1 & 35.32 \\
lower heating value $(\mathrm{Mj} / \mathrm{kg})$ & 86 & 65 & 98.7 \\
Cetan number & 10 & 41 & 42 \\
Latenet heat T $298 \mathrm{~K}(\mathrm{Kj} / \mathrm{kg})$ & 500 & - & 874 \\
Flashpoint $(\mathrm{c})$ & 38 & - & 42 \\
Viscosity, $\left(\mathrm{mm}^{2} / \mathrm{s}\right)$ at $40{ }^{\circ} \mathrm{C}$ & 0.467 & 2.74 & 4.162 \\
Autoignition temperature, ${ }^{\circ} \mathrm{C}$ & $\sim 300$ & - & 416 \\
\hline
\end{tabular}

\subsection{Engine Test}

The fuel engine test was conducted using a single-cylinderTD110 spark ignition engine with a constant compression ratio of 9.5:1. The engine shown in Figure 1 is a naturally aspirated four-stroke portal fuel injection with a total displacement of $230 \mathrm{cc}$ and cylinder bore and piston stroke of $66 \mathrm{~mm}$ and $57 \mathrm{~mm}$, respectively. The engine produced maximum 
power of $3.6 \mathrm{~kW}$ and a maximum speed of $3600 \mathrm{rpm}$. A hydraulic dynamometer was used to apply the desired load on the engine through the control valve that regulates the pump water flow. The adjusted pressure was indicated utilizing a pressure gauge connected to the dynamometer water flow pipe. Digital meters on the measuring panel shown in Figure 2 measure the torque, brake power and temperatures at different points on the engine. Brake-specific fuel consumption (BSFC) of the engine was measured using a glass tube with a $16 \mathrm{~mL}$ bulb, in which the time consumed is measured using a stopwatch. The engine was warmed up for about $15 \mathrm{~min}$. Then, data collection commenced with the tested fuel. Each test was repeated in triplicate, and the average is considered the final result for more accurate and reliable study results.

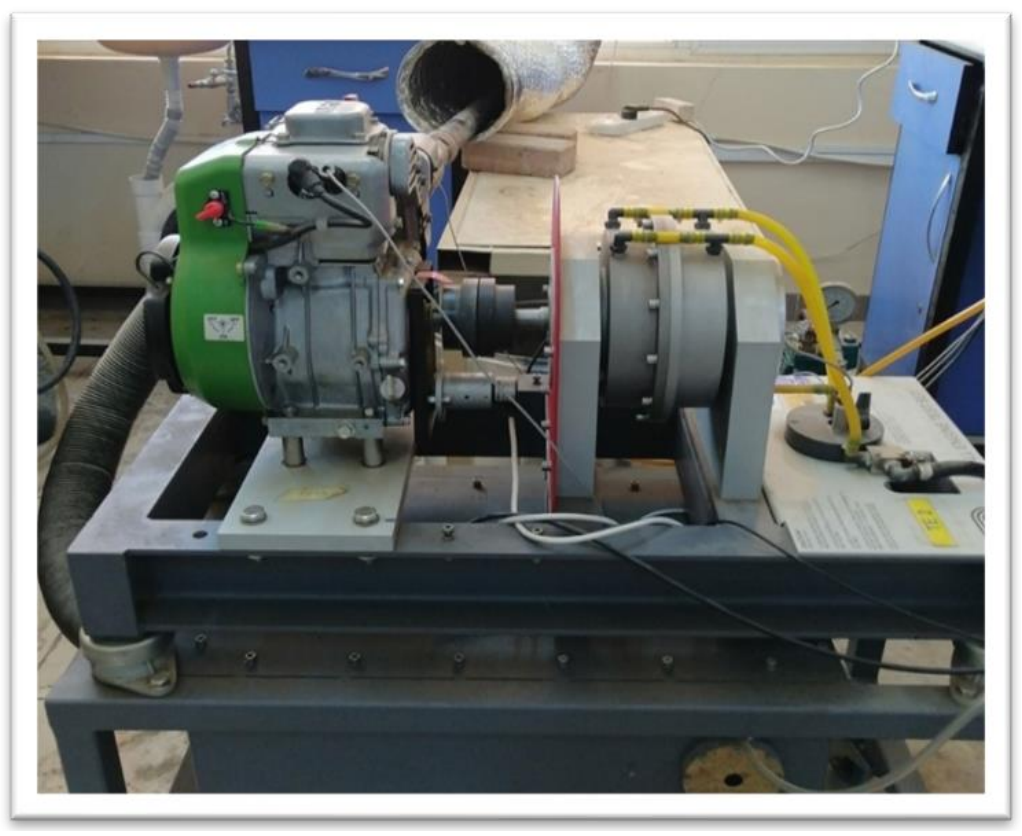

Figure 1. Engine test rig.

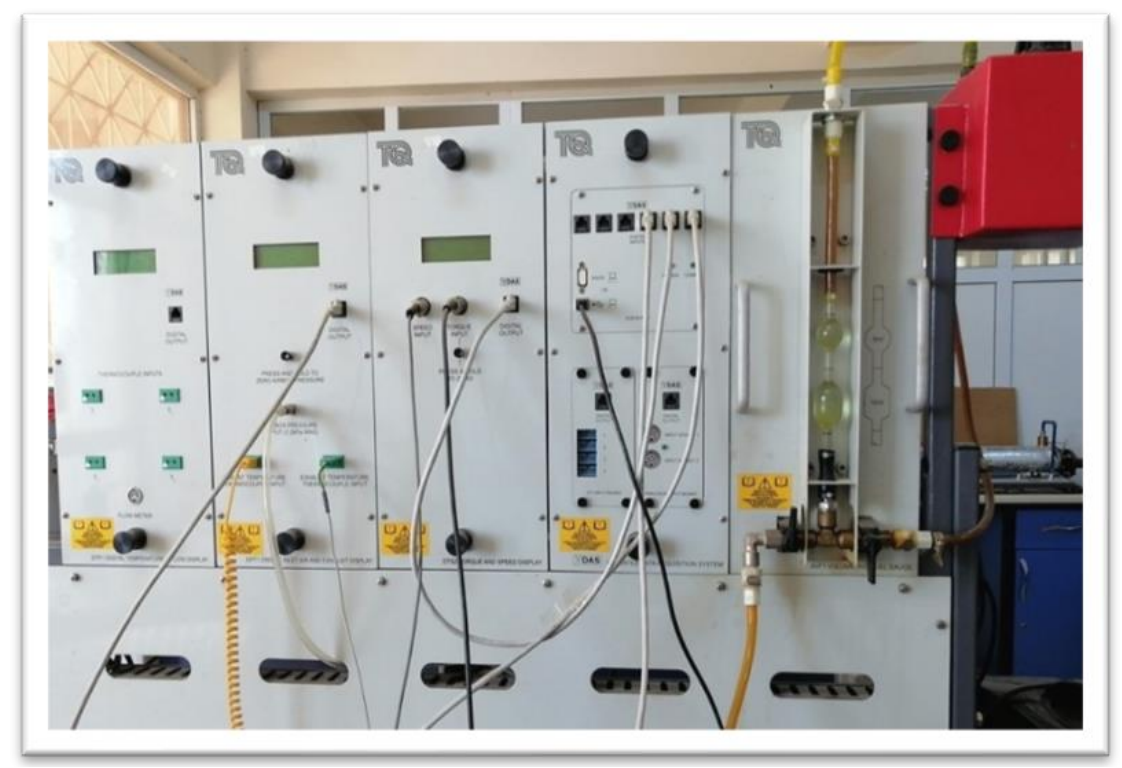

Figure 2. Digital meters on the measuring panel.

\section{Results and Discussion}

When using fuel additives with gasoline, it is essential to evaluate engine performance exhaust emissions as an important indicator for the suitability of fuel blend to operate 
an SI engine efficiently. Although gasoline fuel has different specifications according to the regional fuel standards, SI engines are designed and fabricated by the different manufacturers based on the same standard fuel specifications range. This study tested different fuel samples in SI engine at increasing engine speed within the engine operation range from 1000 to $3000 \mathrm{rpm}$ and constant wide throttle opening (WTO). The results have been studied and discussed to indicate the engine behaviour with different fuel samples.

\subsection{Engine Performance}

Engine brake power represents the noticeable parameter that can be considered to evaluate the output power. It is calculated based on the measured torque and specified engine speed. Figure 3 shows that, in general, engine brake power reveals a similar increasing trend with increasing engine speed using all investigated fuel samples, indicating reasonable behaviour of the tested engine in terms of output power. However, significant variation is observed among the value of brake power obtained with different fuel samples. At low engine speed, the addition of $10 \%$ naphtha and $10 \%$ fusel oil to local gasoline results in an improvement of engine brake power to $0.828 \mathrm{~kW}$ and deterioration to $0.691 \mathrm{~kW}$ respectively compared to $0.765 \mathrm{~kW}$ for local gasoline at $1000 \mathrm{rpm}$, while GN5F5 produced the highest brake power of $0.859 \mathrm{~kW}$. The deviation of engine brake power with GN10 and GF10 converges with increasing engine speed to reach a similar value to $G$ at medium engine speed. At the same time, GN5F5 shows higher brake power compared to other investigated fuel samples. The deviation of engine brake power with GN10 and GF10 was observed again with increasing engine speed. At a high speed of $3000 \mathrm{rpm}$, the addition of $10 \%$ naphtha and $10 \%$ fusel oil to local gasoline fuel results in a deterioration of engine brake power to $2.890 \mathrm{~kW}$ and improvement to $2.576 \mathrm{~kW}$ respectively compared to $2.701 \mathrm{~kW}$ for local gasoline while GN5F5 produced the highest brake power of $2.953 \mathrm{~kW}$ which is higher than that of local gasoline by $9.3 \%$. This is due to the enhancement in both the octane number and heating value of the fuel compared to other fuel samples.

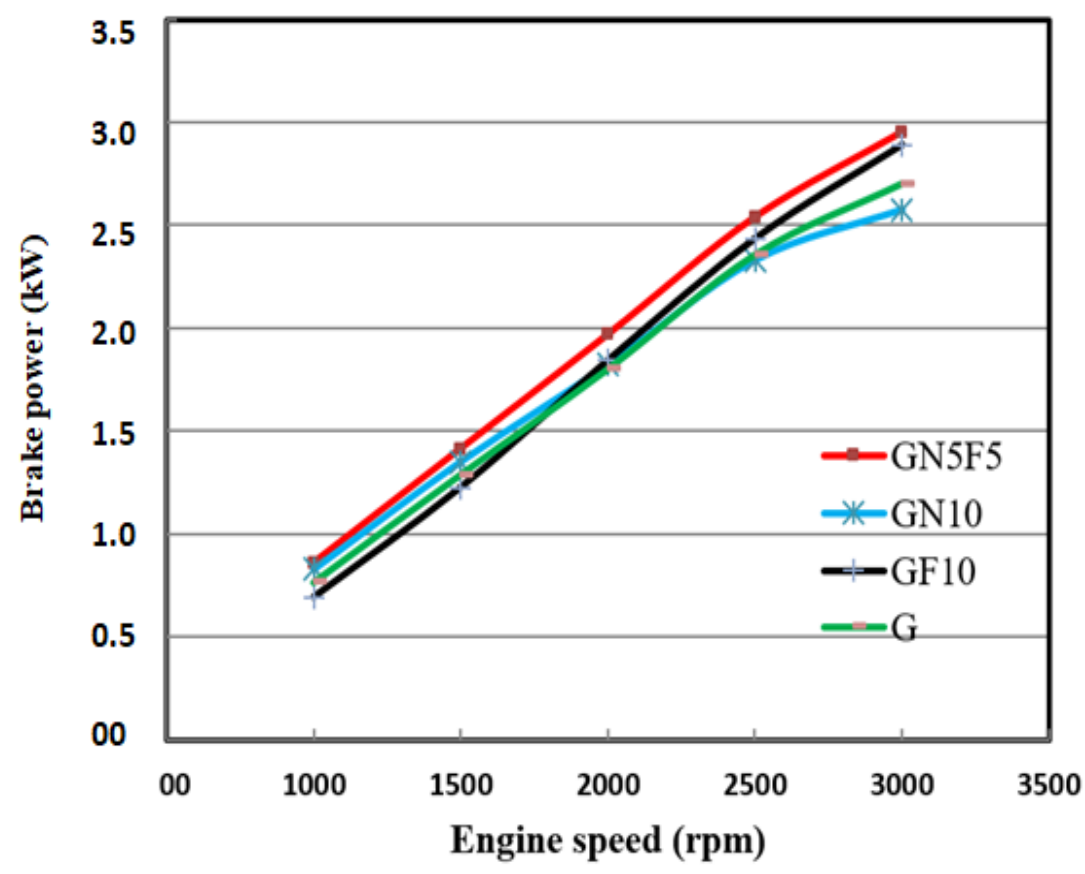

Figure 3. Variation of engine brake power.

\subsection{Brake Specific Fuel Consumption}

Although the engine brake power can be considered to evaluate the engine output power, brake specific fuel consumption (BSFC) is another important indicator for the engine performance assessment. Figure 4 shows that, in general, engine BSFC reveals a similar trend of variation with increasing engine speed using all investigated fuel samples, 
indicating reasonable behaviour of the tested engine in terms of fuel consumption. However, significant variation is observed among the value of BSFC observed with different fuel samples.

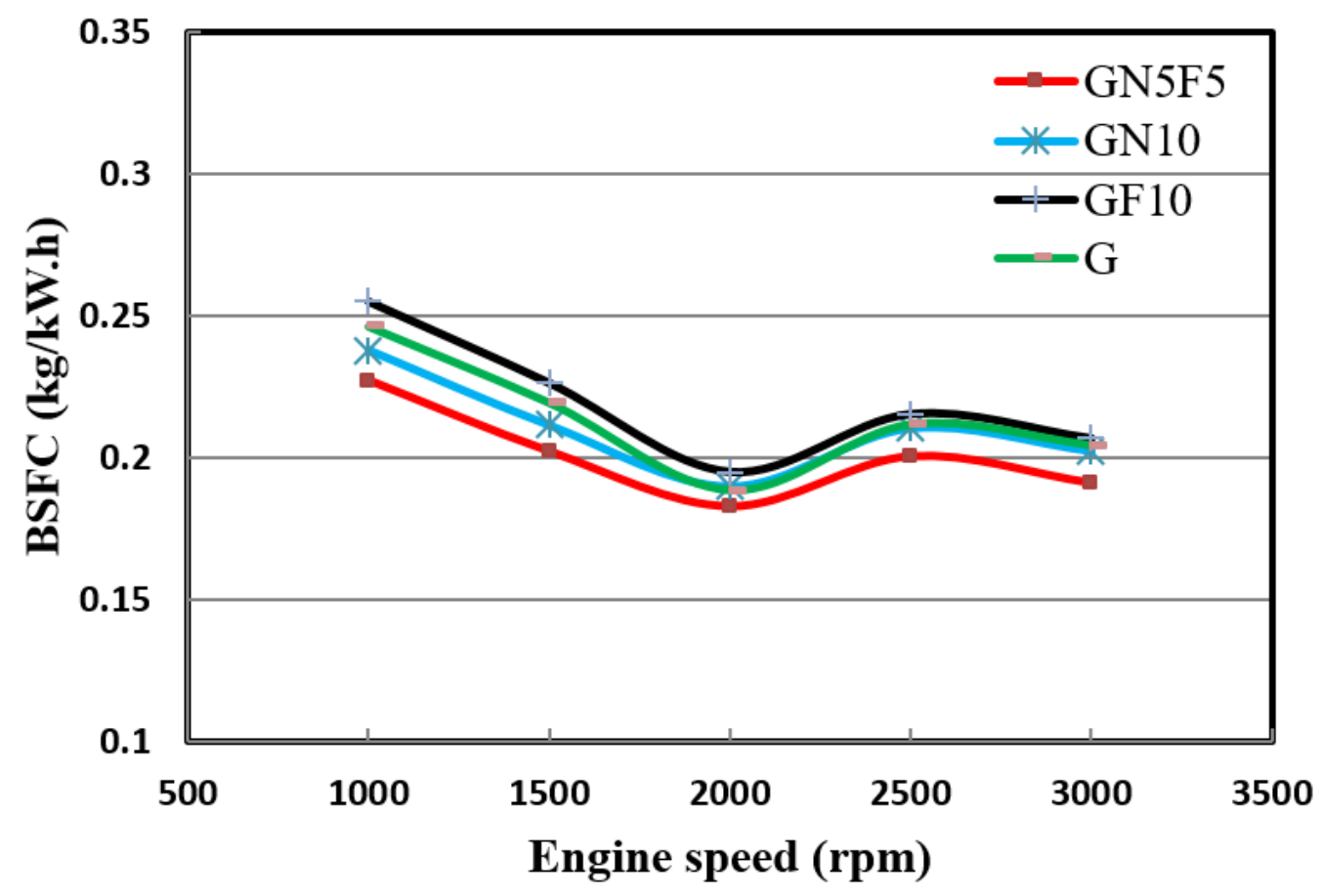

Figure 4. Variation of BSFC.

At low engine speed, adding 10\% naphtha and 10\% fusel oil to local gasoline results in a decrease in BSFC to $0.237 \mathrm{~kg} / \mathrm{kW} . \mathrm{h}$ and an increase to $0.255 \mathrm{~kg} / \mathrm{kW} . \mathrm{h}$ respectively compared to $0.246 \mathrm{~kg} / \mathrm{kW} . \mathrm{h}$ for local gasoline at $1000 \mathrm{rpm}$, while GN5F5 produced the lowest BSFC of $0.227 \mathrm{~kg} / \mathrm{kW}$.h. The deviation of engine brake power with GN10 and GF10 converges with increasing engine speed to reach a similar value to $G$ for GN10 at medium engine speed with a higher value for GF10. At the same time, GN5F5 shows a lower BSFC compared to other investigated fuel samples. The deviation of BSFC with GN10 and GF10 continues to converge with increasing engine speed. At the high speed of $3000 \mathrm{rpm}$, adding $10 \%$ naphtha and $10 \%$ fusel oil to local gasoline fuel results in a comparable BSFC of $0.202 \mathrm{~kg} / \mathrm{kW} . \mathrm{h}$ and $0.206 \mathrm{~kg} / \mathrm{kW} . \mathrm{h}$ respectively compared to $0.204 \mathrm{~kg} / \mathrm{kW} . \mathrm{h}$ for local gasoline, while GN5F5 produced the lowest value of $0.19 \mathrm{~kg} / \mathrm{kW} . \mathrm{h}$, which is lower than that of local gasoline by $6.8 \%$.

\subsection{Brake Thermal Efficiency}

Engine brake thermal efficiency (BTE) is the overall indicator of fuel conversion efficiency and combustion quality. Although engine brake power and brake specific fuel consumption reveal different trends with the investigated fuel samples, brake thermal efficiency can be adopted to evaluate the overall engine performance. Figure 5 shows that, in general, engine BTE reveals a similar trend of variation with increasing engine speed using all investigated fuel samples, which indicates reasonable behaviour of the tested engine in term of BTE. 


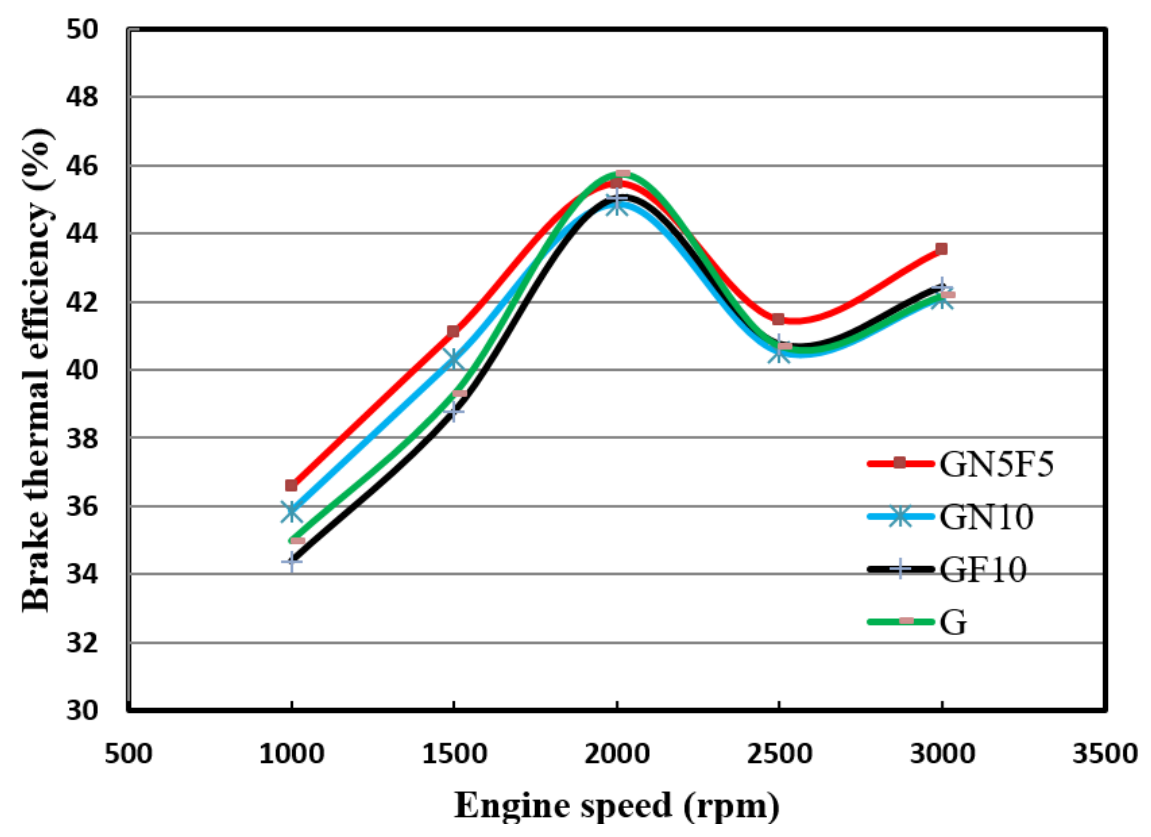

Figure 5. Variation of engine brake thermal efficiency.

However, significant variation is observed among the values of BTE with different fuel samples. At low engine speed, the addition of $10 \%$ naphtha and $10 \%$ fusel oil to local gasoline results in an increase in BTE to $35.85 \%$ and deterioration to $34.4 \%$ respectively compared to $34.8 \%$ for local gasoline at $1000 \mathrm{rpm}$, while GN5F5 produced the highest BTE of $36.57 \%$. The deviation of engine brake power with GN10 and GF10 converge with increasing engine speed to reach a similar value at medium engine speed with a higher value for G and GN5F5. The convergence of BTE with GN10 and GF10 in addition to G continue with increasing engine speed to reach comparable values at the high speed of $3000 \mathrm{rpm}$. On the other hand, the higher BTE was observed for GN5F5 with increasing engine speed, which is higher than that of local gasoline by $3.2 \%$.

\subsection{Exhaust Emission}

Exhaust emissions are important indicators for the suitability of the suggested fuel for operating an SI engine, especially with the current legislation restricting the emitted pollutants that contributes to global warming. The emission of carbon monoxide (CO) derives from the incomplete combustion of the air-fuel mixture in the combustion chamber and is affected strongly by the temperature at the end of the combustion phase. Figure 6 presents the variation of $\mathrm{CO}$ emissions for different tested fuel samples with increasing engine speed. The higher CO emissions were obtained with GN10 followed by pure gasoline approximately over the entire engine speed. Both naphtha and gasoline are hydrocarbon fuels that tend to provide incomplete oxidation during the combustion in the combustion chamber. However, adding fusel oil to gasoline results in complete oxidation, reducing the generation of $\mathrm{CO}$ emissions. Minimum $\mathrm{CO}$ emissions were observed with GN5F5 over the whole engine speed. This may be attributed to the higher oxygen content of fusel oil and the moderate effect of octane number and heating value of naphtha and fusel oil on the mixture combustion temperature, which indicates complete combustion. 


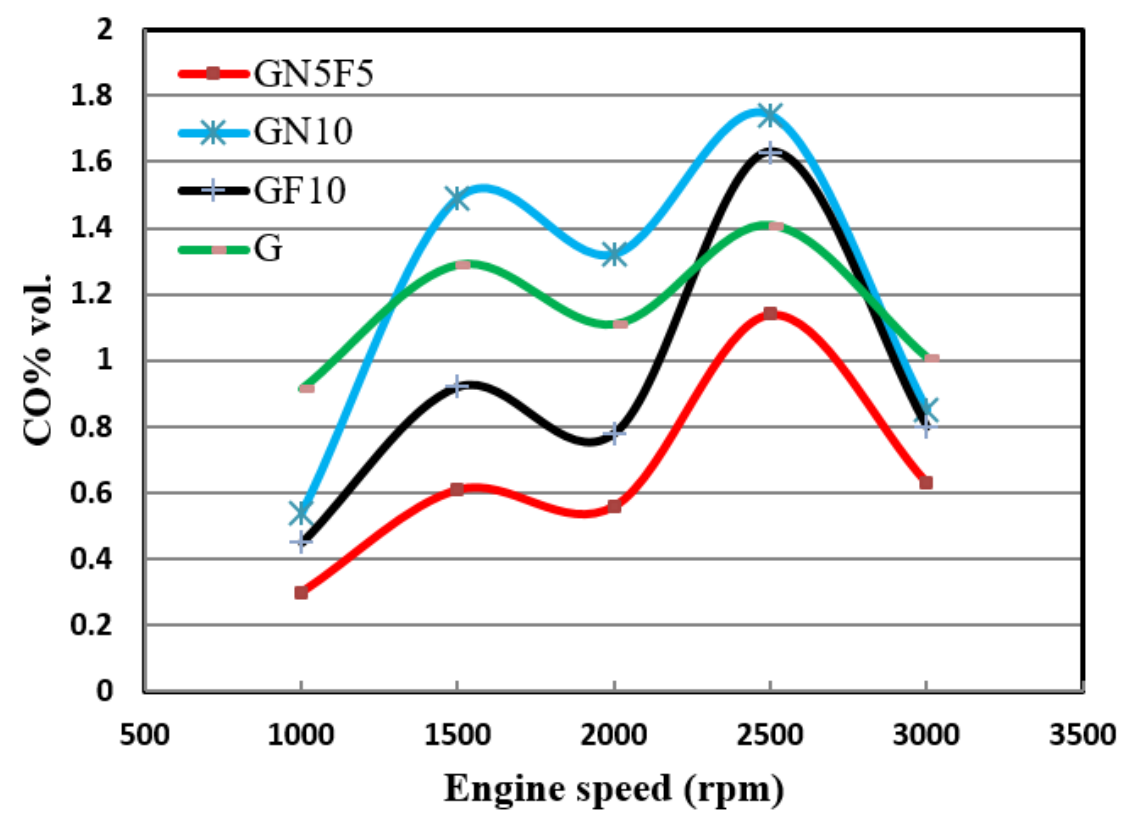

Figure 6. Variation of $\mathrm{CO}$ emissions.

The emission of carbon dioxide $\left(\mathrm{CO}_{2}\right)$ derived from the complete combustion of the air-fuel mixture in the combustion chamber is affected strongly by the oxygen content. Figure 7 presents the variation of $\mathrm{CO}_{2}$ emissions for different tested fuel samples with increasing engine speed. The higher $\mathrm{CO}_{2}$ emissions obtained with GF10 over the entire engine speed may be attributed to the higher oxygen content of fusel oil. Both naphtha and gasoline showed lower observed $\mathrm{CO}_{2}$ emissions. However, GN5F5 shows a slight increment in the generation of CO emissions, which is lower than that of GF10. This may be attributed to the higher oxygen content of fusel oil and the moderate effect of the octane number of naphtha on fuel mixture combustion, which indicates complete combustion.

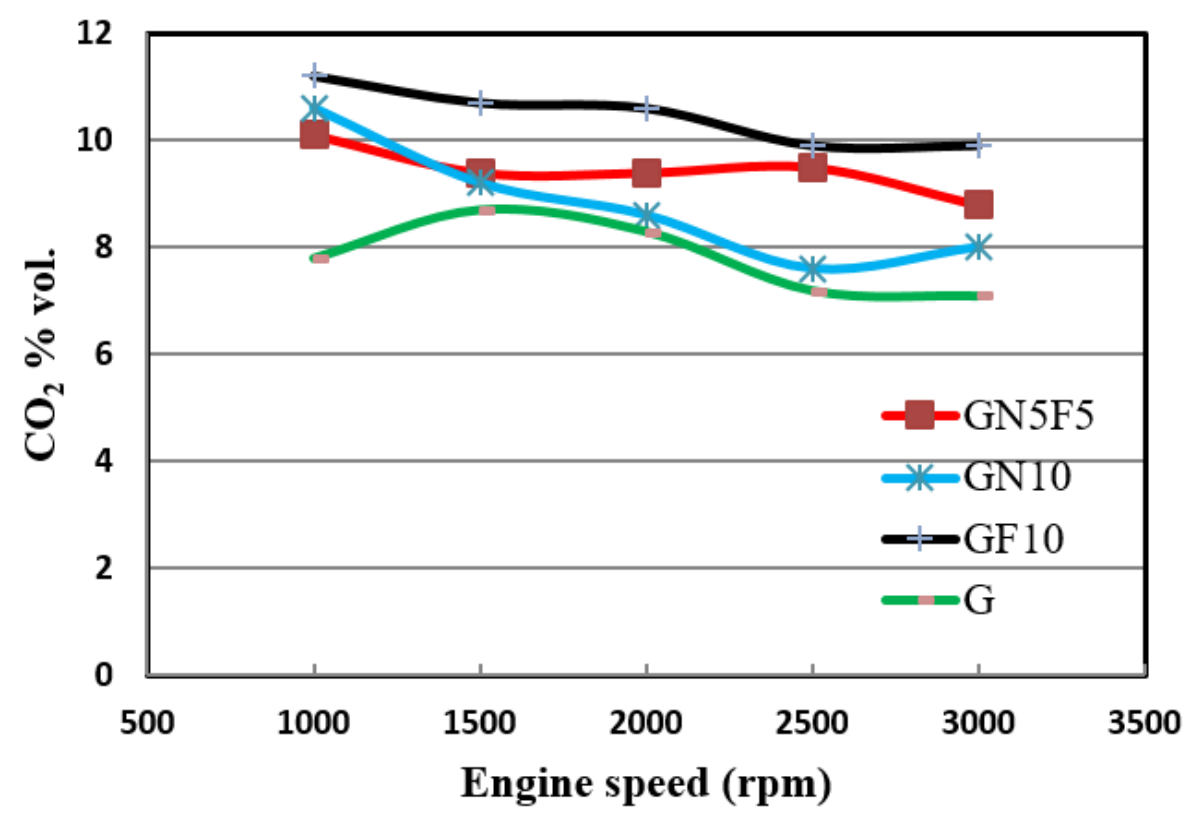

Figure 7. Variation of $\mathrm{CO}_{2}$ emissions.

$\mathrm{NO}$ and $\mathrm{NO}_{2}$ are the most common nitrogen oxides as the other oxides quantities are relatively small. $\mathrm{NO}_{\mathrm{x}}$ is formed as a by-product from the oxidation of nitrogen molecules inside the cylinder at a high temperature. Most of the literature indicated a reduction in $\mathrm{NO}_{\mathrm{x}}$ emission with increasing alcoholic fuel content. 
The variations of $\mathrm{NO}_{x}$ emissions for different tested fuel samples with increasing engine speed are shown in Figure 8. In general, the $\mathrm{NO}_{\mathrm{x}}$ emissions were decreased as the engine speed increased. The $\mathrm{NO}_{x}$ emission of gasoline is the highest, while that for GF10 is the lowest, which could be explained by the lower in-cylinder temperature due to the cooling effect of fusel oil during the combustion phase. GN5F5 shows slightly higher $\mathrm{NO}_{\mathrm{x}}$ emissions than GF10, which is lower than that of GN10 and gasoline.

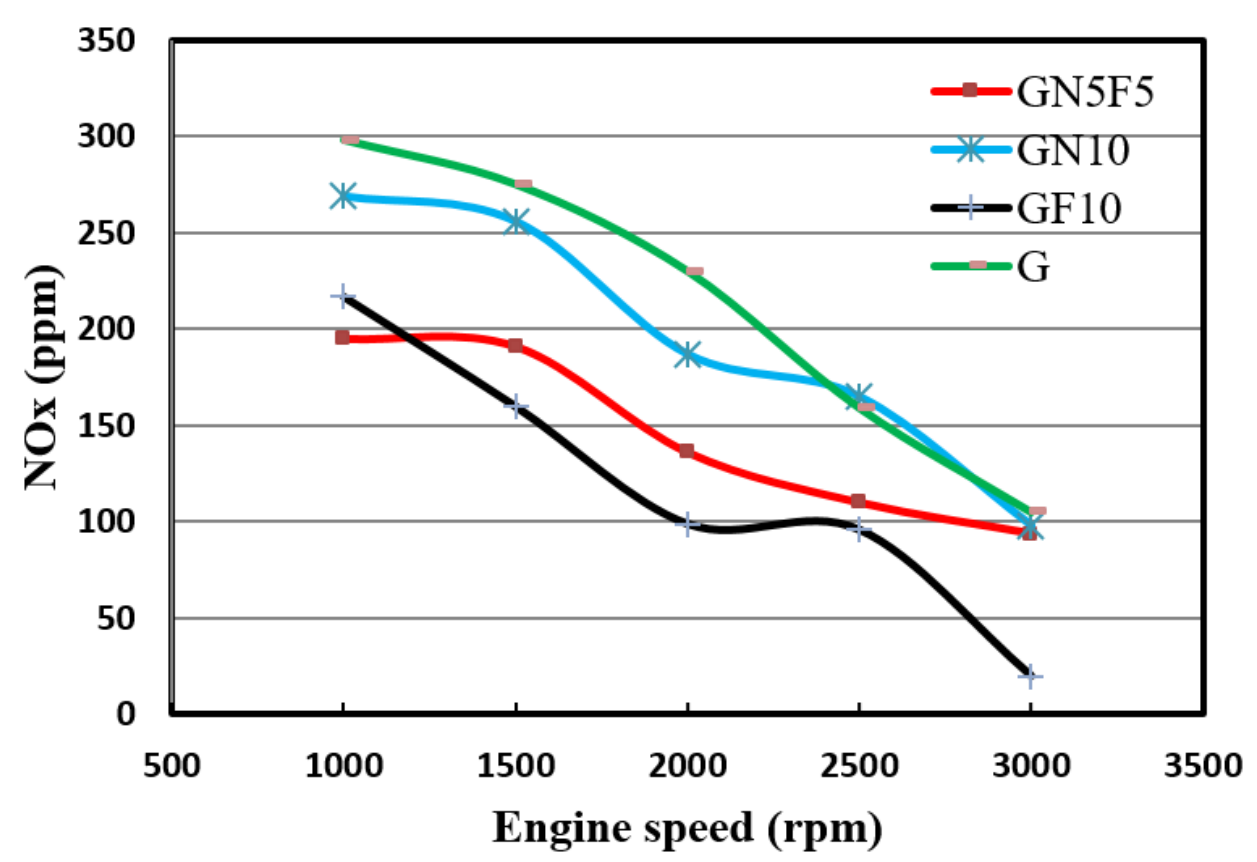

Figure 8. Variation of $\mathrm{NO}_{\mathrm{x}}$ emissions.

\section{Conclusions}

When using fuel additives with gasoline, it is essential to evaluate engine performance exhaust emissions. In this study, fusel oil as octane enhancer and naphtha as an additive with high energy content to the commercial gasoline fuel have been investigated. A blend of commercial gasoline, light naphtha, and fusel oil was used to operate a gasoline engine. Different blends have been investigated in this study, including GN10, GF10, GN5F5, and pure commercial gasoline (G100). Based on the property characterization and engine test results, the following conclusions can be addressed:

1. GN5F5 shows higher brake power and lower brake-specific fuel consumption compared to other investigated fuel samples over the whole engine speed.

2. Significant variation was observed among the values of BTE with different fuel samples and the higher BTE was observed for GN5F5.

3. Varying engine performance was obtained with GN10 and GF10 at increasing engine speed compared to local gasoline fuel (G).

4. The higher CO emissions were obtained with GN10 followed by pure gasoline approximately over the entire engine speed range and the minimum $\mathrm{CO}$ emissions were observed with GN5F5.

5. The higher $\mathrm{CO}_{2}$ emissions were obtained with GF10 over the entire engine speed while GN5F5 shows a slight increment in the generation of CO emissions, lower than that of GF10.

6. Gasoline emits higher $\mathrm{NO}_{\mathrm{x}}$ emissions while GF10 is the lowest. GN5F5 shows slightly higher $\mathrm{NO}_{\mathrm{x}}$ emissions than GF10, which is lower than GN10 and gasoline.

Finally, it can be concluded that GN5F5 was observed to be a better mixing blend in terms of engine performance and exhaust emissions. This fuel mix can be adopted to enhance engine operation using locally available fuel additives, which mitigates environmental pollution, especially when using waste by-product additives. 
Author Contributions: Conceptualization, O.M.A. (Obed Majeed Ali) and O.R.A.; methodology, O.M.A. (Obed Majeed Ali), O.R.A. and O.M.A. (Omar Mohammed Ali); software, O.M.A. (Obed Majeed Ali) and O.R.A.; validation, O.M.A. (Obed Majeed Ali), N.T.A., S.A., M.A. and A.N.; formal analysis, O.M.A. (Omar Mohammed Ali), S.J.Y., N.T.A. and A.N.; investigation, O.M.A. (Obed Majeed Ali), O.R.A., A.N. and M.A.; resources, O.M.A. (Omar Mohammed Ali), S.J.Y. and N.T.A.; writing-original draft preparation, O.M.A. (Obed Majeed Ali), O.R.A. and O.M.A. (Omar Mohammed Ali); writingreview and editing-O.M.A. (Obed Majeed Ali), S.J.Y., N.T.A., A.N., M.A. and S.A.; visualization, O.M.A. (Obed Majeed Ali), N.T.A., S.J.Y. and M.A.; supervision, O.M.A. (Obed Majeed Ali) and O.R.A.; project administration, O.M.A. (Obed Majeed Ali) and O.R.A.; funding acquisition, S.A. All authors have read and agreed to the published version of the manuscript.

Funding: This project has been funded by King Saud University, Riyadh, Saudi Arabia under project number RSP-2021/167.

Institutional Review Board Statement: Not applicable.

Informed Consent Statement: Not applicable.

Data Availability Statement: Not applicable.

Conflicts of Interest: The authors declare no conflict of interest.

\section{References}

1. Göktaş, M.; Kemal Balki, M.; Sayin, C.; Canakci, M. An evaluation of the use of alcohol fuels in SI engines in terms of performance, emission and combustion characteristics: A review. Fuel 2021, 286, 119425. [CrossRef]

2. Li, D.; Wang, H.; Yu, X.; Yang, H. Combustion and emission characteristics of an Acetone-Butanol-Ethanol (ABE) spark ignition engine with hydrogen direct injection. Int. J. Hydrog. Energy 2021, 46, 30145-30157. [CrossRef]

3. Han, D.; Fan, Y.; Sun, Z.; Nour, M.; Li, X. Combustion and emissions of isomeric butanol/gasoline surrogates blends on an optical GDI engine. Fuel 2020, 272, 117690. [CrossRef]

4. Ardebili, S.; Solmaz, H.; İpci, D.; Calam, A.; Mostafaei, M. A review on higher alcohol of fusel oil as a renewable fuel for internal combustion engines: Applications, challenges, and global potential. Fuel 2020, 279, 118516. [CrossRef]

5. Talebian-kiakalaieh, A.; Aishah, N.; Amin, S.; Mazaheri, H. A review on novel processes of biodiesel production from waste cooking oil. Appl. Energy 2013, 104, 683-710. [CrossRef]

6. Awad, O.I.; Mamat, R.; Ali, O.M.; Sidik, N.A.C.; Yusaf, T.; Kadirgama, K.; Kettner, M. Alcohol and ether as alternative fuels in spark ignition engine: A review. Renew. Sustain. Energy Rev. 2018, 82, 2586-2605. [CrossRef]

7. Rezania, S.; Mahdinia, S.; Oryani, B.; Cho, J.; Kwon, E.E.; Bozorgian, A.; Rashidi Nodeh, H.; Darajeh, N.; Mehranzamir, K. Biodiesel production from wild mustard (Sinapis Arvensis) seed oil using a novel heterogeneous catalyst of LaTiO3 nanoparticles. Fuel 2022, 307, 121759. [CrossRef]

8. Im-orb, K.; Arpornwichanop, A.; Simasatitkul, L. Process intensification approach for design and optimization of biodiesel production from palm fatty acid distillate. Biotechnol. Reports 2021, 30, e00622. [CrossRef]

9. Chen, Z.; Wang, L.; Zeng, K. Comparative study of combustion process and cycle-by-cycle variations of spark-ignition engine fueled with pure methanol, ethanol, and n-butanol at various air-fuel ratios. Fuel 2019, 254, 115683. [CrossRef]

10. Veza, I.; Said, M.F.M.; Latiff, Z.A. Progress of acetone-butanol-ethanol (ABE) as biofuel in gasoline and diesel engine: A review. Fuel Process. Technol. 2019, 196, 106179. [CrossRef]

11. Fangfang, F.; Alagumalai, A.; Mahian, O. Sustainable biodiesel production from waste cooking oil: ANN modeling and environmental factor assessment. Sustain. Energy Technol. Assess. 2021, 46, 101265. [CrossRef]

12. Safieddin Ardebili, S.M.; Taghipoor, A.; Solmaz, H.; Mostafaei, M. The effect of nano-biochar on the performance and emissions of a diesel engine fueled with fusel oil-diesel fuel. Fuel 2020, 268, 117356. [CrossRef]

13. Mishra, S.R.; Mohanty, M.K.; Panigrahi, N.; Pattanaik, A.K. Impact of Simarouba glauca biodiesel blends as a fuel on the performance and emission analysis in an unmodified DICI engine. Renew. Energy Focus 2018, 26, 11-16. [CrossRef]

14. Abu-Hamdeh, N.H.; Bantan, R.A.; Khoshvaght-Aliabadi, M.; Alimoradi, A. Effects of ribs on thermal performance of curved absorber tube used in cylindrical solar collectors. Renew. Energy 2020, 161, 1260-1275. [CrossRef]

15. Hosseinpour Vardin, F.; Najafi, B. Developing a novel downdraft fixed bed gasifier for hydrogen production from sawdust to improve an SI engine exhaust emissions. Renew. Energy Focus 2018, 27, 88-96. [CrossRef]

16. Awad, O.I.; Ali, O.M.; Mamat, R.; Abdullah, A.A.; Najafi, G.; Kamarulzaman, M.K.; Yusri, I.M.; Noor, M.M. Using fusel oil as a blend in gasoline to improve SI engine efficiencies: A comprehensive review. Renew. Sustain. Energy Rev. 2017, 69, 1232-1242. [CrossRef]

17. Rosdia, S.M.; Mamata, R.; Azri, A.; Sudhakar, K.; Yusri, I.M. Evaluation of properties on performance and emission to turbocharged SI engine using fusel oil blend with gasoline. IOP Conf. Ser. Mater. Sci. Eng. 2019, 469. [CrossRef]

18. Abdellatief, T.M.M.; Ershov, M.A.; Kapustin, V.M.; Ali Abdelkareem, M.; Kamil, M.; Olabi, A.G. Recent trends for introducing promising fuel components to enhance the anti-knock quality of gasoline: A systematic review. Fuel 2021, 291, 120112. [CrossRef] 
19. Calam, A.; Aydoğan, B.; Halis, S. The comparison of combustion, engine performance and emission characteristics of ethanol, methanol, fusel oil, butanol, isopropanol and naphtha with n-heptane blends on HCCI engine. Fuel 2020, 266, 117071. [CrossRef]

20. Wang, C.; Chahal, J.; Janssen, A.; Cracknell, R.; Xu, H. Investigation of gasoline containing GTL naphtha in a spark ignition engine at full load conditions. Fuel 2017, 194, 436-447. [CrossRef]

21. Çelebi, S.; Duzcan, B.; Demir, U.; Uyumaz, A.; Haşimoglu, C. Effects of light naphtha utilization on engine performance in an homogeneous charged compression ignition engine. Fuel 2021, 306, 121663. [CrossRef]

22. Wu, Z.; Wang, L.; Badra, J.A.; Roberts, W.L.; Fang, T. GDI fuel sprays of light naphtha, PRF95 and gasoline using a piezoelectric injector under different ambient pressures. Fuel 2018, 223, 294-311. [CrossRef]

23. Rockstroh, T.; Floweday, G.; Wilken, C. Options for Use of GTL Naphtha as a Blending Component in Oxygenated Gasoline. SAE Int. J. Fuels Lubr. 2016, 9, 191-202. [CrossRef]

24. Wang, L.; Badra, J.A.; Roberts, W.L.; Fang, T. Characteristics of spray from a GDI fuel injector for naphtha and surrogate fuels. Fuel 2017, 190, 113-128. [CrossRef]

25. Vallinayagam, R.; An, Y.; Vedharaj, S.; Sim, J.; Chang, J.; Johansson, B. Naphtha vs. dieseline-The effect of fuel properties on combustion homogeneity in transition from CI combustion towards HCCI. Fuel 2018, 224, 451-460. [CrossRef]

26. Kocakulak, T.; Babagiray, M.; Nacak, Ç.; Safieddin Ardebili, S.M.; Calam, A.; Solmaz, H. Multi objective optimization of HCCI combustion fuelled with fusel oil and n-heptane blends. Renew. Energy 2021, 182, 827-841. [CrossRef]

27. Yang, H.; Shuai, S.; Wang, Z.; Wang, J.; Xu, H. New premixed compression ignition concept for direct injection IC engines fueled with straight-run naphtha. Energy Convers. Manag. 2013, 68, 161-168. [CrossRef]

28. Javed, T.; Nasir, E.F.; Ahmed, A.; Badra, J.; Djebbi, K.; Beshir, M.; Ji, W.; Sarathy, S.M.; Farooq, A. Ignition delay measurements of light naphtha: A fully blended low octane fuel. Proc. Combust. Inst. 2017, 36, 315-322. [CrossRef]

29. Wang, L.; Wu, Z.; Ahmed, A.; Badra, J.A.; Sarathy, S.M.; Roberts, W.L.; Fang, T. Auto-ignition of direct injection spray of light naphtha, primary reference fuels, gasoline and gasoline surrogate. Energy 2019, 170, 375-390. [CrossRef]

30. Alabbad, M.; Issayev, G.; Badra, J.; Voice, A.K.; Giri, B.R.; Djebbi, K.; Ahmed, A.; Sarathy, S.M.; Farooq, A. Autoignition of straight-run naphtha: A promising fuel for advanced compression ignition engines. Combust. Flame 2018, 189, 337-346. [CrossRef]

31. Lu, A.; Zhang, C.; Ren, Y.; Li, Y.; Li, S.; Yin, P. Research on knock recognition of coal-based naphtha homogeneous charge compression ignition engine based on combined feature extraction and classification. Fuel 2021, 300, 120997. [CrossRef]

32. Wang, B.; Wang, Z.; Shuai, S.; Yang, H.; Wang, J. Combustion and emission characteristics of Multiple Premixed Compression Ignition (MPCI) fuelled with naphtha and gasoline in wide load range. Energy Convers. Manag. 2014, 88, 79-87. [CrossRef]

33. Simsek, S.; Uslu, S. Experimental study of the performance and emissions characteristics of fusel oil/gasoline blends in spark ignited engine using response surface methodology. Fuel 2020, 277, 118182. [CrossRef]

34. Safieddin Ardebili, S.M.; Solmaz, H.; Mostafaei, M. Optimization of fusel oil-Gasoline blend ratio to enhance the performance and reduce emissions. Appl. Therm. Eng. 2019, 148, 1334-1345. [CrossRef]

35. Abdalla, A.N.; Tao, H.; Bagaber, S.A.; Ali, O.M.; Kamil, M.; Ma, X.; Awad, O.I. Prediction of emissions and performance of a gasoline engine running with fusel oil-gasoline blends using response surface methodology. Fuel 2019, 253, 1-14. [CrossRef] 